\title{
Avaliação da resposta imune humoral em camundongos para a proteína Glutationa S-transferase de Rhipicephalus (Boophilus) microplus (GST-Bm), e de Haemaphysalis longicornis (GST-HI)*
}

\author{
KIYOKO UEMURA UTIUMI
}

\author{
Itabajara da Silva Vaz J unior (Orientador - UFRGS)
}

Aoi Masuda (Co-orientadora - UFRGS)

Banca: Elizabeth Cirne Lima (UFRGS), John Furlong (EMBRAPA-MG), Mario Augusto Ono (UEL)

O carrapato Rhipicephalus (Boophilus) microplus é um ectoparasito hematófago que infesta os rebanhos bovinos de regiões tropicais e subtropicais, e é um dos principais causadores de prejuízos econômicos à pecuária. O principal método de controle baseia-se no uso de acaricidas. No entanto, devido à crescente preocupação com os problemas criados pela poluição química do meio ambiente, ao alto custo e toxicidade das drogas e ao aparecimento de carrapatos resistentes aos acaricidas, métodos alternativos para o controle do $R$. microplus devem ser encontrados. Um dos métodos alternativos estudados é o uso de vacinas. As Glutationa S-transferases (GST) são enzimas que estão presentes em organismos animais e vegetais e, entre suas funções, podem-se destacar transporte intracelular, participação em processos digestivos, síntese de prostaglandinas, e detoxificação de substâncias tóxicas e proteção contra estresse oxidativo. Neste estudo, foi analisada a resposta imunológica comparativa de camundongos para a GST de R. microplus (GST-Bm) e para a GST de Haemaphysalis longicornis (GST-Hl). Ambas as proteínas foram expressas em Escherichia coli linhagem AD494, e purificadas por cromatografia de afinidade por glutationa utilizando a coluna GSTrap FF. Para verificar a imunogenicidade das proteínas, foram utilizados 25 camundongos Balb/c divididos em 12 grupos. As condições testadas foram as inoculações das proteínas GST-Bm e GST-Hl com os adjuvantes Montanide, saponina ou sem adjuvantes. Camundongos controle foram inoculados com extrato de E. coli ou somente com os adjuvantes. Foi coletado sangue de todos os animais, com intervalos de sete dias, durante 70 dias. Os soros foram analisados por ELISA para acompanhar a cinética da produção de anticorpos de todos os animais imunizados. Os camundongos inoculados com GST-Hl emulsificada com Montanide mostraram aumento dos níveis de anticorpos a partir do dia 21 . O nível máximo de anticorpos foi detectado no dia 42, e diminuiu após o dia 56. Todos os outros animais não apresentaram aumento nos níveis de anticorpos.

Descritores: Rhipicephalus (B) microplus, Haemaphysalis longicornis, GST-Bm, GST-Hl, ELISA, vacinas, carrapato, bovinos.

\footnotetext{
*Dissertação de Mestrado n. 484 (Especialidade: Imunologia Aplicada). 65f. Programa de Pós-graduação e Ciências Veterinárias [www.ufrgs.br/ ppgcv], Faculdade de Veterinária, Universidade Federal do Rio Grande do Sul (UFRGS), Porto Alegre/RS. CORRESPONDÊNCIA: L. D. Silva [alemdvet@yahoo.com.br].
} 


\title{
Evaluation of immune humoral response in mice for protein Glutathione S-transferase of Rhipicephalus (Boophilus) microplus (GST-Bm), and Haemaphysalis longicornis (GST-HI)**
}

KIYOKO UEMURA UTIUMI

\author{
Itabajara da Silva Vaz J unior (Adviser - UFRGS)
}

Aoi Masuda (Co-adviser - UFRGS)

Committee: Elizabeth Cirne Lima (UFRGS), John Furlong (EMBRAPA-MG), Mario Augusto Ono (UEL)

Rhipicephalus (Boophilus) microplus tick is a hematophagous ectoparasite that infests cattle in tropical and subtropical regions and is one of the principal causes of economic losses in the cattle farm. The principal method of control is the use of acaricides. However, due to increased worry about environmental chemical pollution, high costs and drugs toxicity and the selection of ticks resistant to acaricides, alternative methods for $R$. microplus control should be developed. One of these methods is vaccination. Glutathione S-transferases (GSTs) enzymes are present in animal and vegetal organisms and the functions are intracellular transport, participation in digestive process, synthesis of prostaglandins and detoxification of toxic substances and protection against oxidative stress. In this study the immunological response of mice inoculated with $R$. microplus GST (GST-Bm) and with Haemaphysalis longicornis GST (GST-Hl) was analysed. Both proteins were expressed in Escherichia coli strain AD494 and were purified by affinity chromatography using GSTrap FF columm. To verify the protein immunogenicity, $25 \mathrm{Balb} / \mathrm{c}$ mice divided into 12 groups were used. The tested conditions were inoculation of GST-Bm, GST$\mathrm{Hl}$ proteins with Montanide and saponin adjuvants or without adjuvant. Control mice were inoculated with $E$. coli extract or the adjuvant alone. Blood from all animals were collected with intervals of seven days during seventy days, the sera were analyzed by ELISA to verify the kinetic of antibodies production of all immunized animals. Mice inoculated with GST-HI emulsified with Montanide showed an increase in the antibodies levels from day 21. The maximum level of antibodies was detected on day 42 and decreased after day 56. The other animals did not show an increase in antibodies levels.

Key words: Rhipicephalus (B) microplus, Haemaphysalis longicornis, GST-Bm, GST-Hl, ELISA, vaccines, ticks, bovines.

Presented: 11 February 2008

**Master's Thesis \#484 (Field: Immunology). 65p. Graduate Program in Veterinary Sciences [www.ufrgs.br/ppgcv], Faculdade de Veterinária, Universidade Federal do Rio Grande do Sul (UFRGS), Porto Alegre/Brazil. CORRESPONDENCE: L.D. Silva [alemdvet@yahoo.com.br]. 